\title{
Complement or substitute: Ethanol's uncertain relationship with gasoline under alternative petroleum price and policy scenarios
}

\section{Introduction}

Ethanol accounts for a larger share of global liquid fuels markets than ever before, but interactions between ethanol and fossil fuel sources are complicated by varying consumer uses and policy interventions. Since 2000, total energy consumption in the global transportation sector has been increasing $2 \%$ annually, and global ethanol production has risen from 28.5 billion liters in 2004 to 98 billion liters in 2015 [1]. In 2015, renewable energy use in the road transportation sector is estimated to be $4 \%$ of the total transportation fuel use and liquid biofuels, including ethanol, dominate among all other renewable fuels in this sector [1]. Ethanol is the most widely used biofuel that is blended with and displaces petroleum-based fossil fuel, leading to greenhouse gas emission (GHG) reductions [2]. While the recent increase has attracted attention, Brazil has

been using ethanol as a fuel since 1925 [3]. In the U.S. and E.U., as in Brazil, government policies intervene in biofuel markets by setting minimum quantities or shares of domestic use, but these policies tend to be complex. For example, the U.S. Renewable Fuel Standard (RFS) sets a hierarchy of volume targets by biofuel type while allowing for waivers based, in part, on market conditions [4]. Ethanol use has grown in importance, but the interaction of demand and policy drivers is difficult to assess because this market has evolved so quickly and so recently in most countries.

The effect of petroleum price changes on ethanol markets and policies is uncertain yet important. The uncertainty relates to the sudden increase in this market and the nature of demand. As global ethanol use has more than doubled in just a decade, historical data might not represent current market conditions. Moreover, as shown later, demand is likely to be non-linear, ranging 
26 from a complementary relationship with gasoline at very low volumes where it is used as a fuel

27 additive to influence its physical properties, to a strong substituting relationship as fuels with high

28 ethanol inclusion rate displace petroleum products. In addition, these relationships can be

29 influenced by policies that set minimum use targets, particularly if a fixed blend is required.

30 Estimates drawn from decades of U.S. data, for example, might span periods when the marginal

31 use of ethanol was as an additive and periods when the marginal use was as a competing fuel

32 source. Future interactions are uncertain.

The importance of these interactions is without doubt. Scientific assessment of supply

34 chains and environmental impacts demonstrates the broad relevance of ethanol (e.g. [5, 6, 7]).

35 Debates in the U.S. Congress, during the Presidential campaigns, and in the industry press about

36 the details and very existence of the RFS show that the policy should be a subject of applied

37 energy economics. The U.S. mandates affect markets and can cause billions of dollars in

38 compliance costs for obligated parties, as discussed below. Looking ahead towards the legislated

39 increases in the mandate and taking into account an uncertain petroleum price and its implications

40 for ethanol demand, applied research has a role in outlining the potential market and policy cost

41 impacts.

\section{2. Background}

Estimates over past data might not relate to market conditions in the future and, moreover,

44 time series methods focusing on price series tend not to address the mandate compliance costs.

45 The linkage between food and fuel markets has been discussed in the applied economic literature

46 for many years. Serra and Zilberman [9] review time series studies of prices and find that, in

47 general, energy prices tend to drive agricultural commodity prices historically. Serra et al. [10],

48 Serra et al. [11], Whistance et al. [12], Whistance and Thompson [13], and Zhang et al. [14] use 
49 time series analysis for both U.S. and Brazilian biofuel markets to estimate links between ethanol,

50 petroleum-based fuels, and crop prices. They found that an increase in the petroleum prices

51 results in an increase in the ethanol price and, consequently, an increase in the prices of corn in

52 the U.S. and sugar in Brazil. However, very few of these studies rely primarily on recent data and

53 also exploit information about U.S. mandate compliance [12, 13]. These studies argue that the

54 linkage between food and fuel prices depends on the relationship between biofuels and gasoline.

55 If biofuels complement petroleum products, as might be true in the case of fuels with a $10 \%$

56 ethanol inclusion rate (E10) in the U.S. (Fig. 1), then a high gasoline price will cause a decrease

57 in biofuel use and can lower feedstock prices. Conversely, if biofuels and petroleum products are

58 substitutes, as in the case of hydrous ethanol in Brazil (Fig. 2), then rising petroleum-based fuel

59 prices increase biofuel demand and increase the prices of crops that are used as feedstocks.

60 Demirbas [15] and Szklo et al. [16] point out that there are both complementary and substitute

61 relationships between ethanol and gasoline. However, this line of work tends to be backward-

62 looking, whereas future market conditions might differ if there are changes in petroleum price

63 levels, mandated volumes or shares, or the relationship between ethanol and petroleum products

64 at the margin. Moreover, studies that represent ethanol as either a complement to gasoline (Fig. 1)

65 or a substitute (Fig. 2) could be completely incorrect about price relationships if the switch from

66 one segment of demand to the other is not taken into account.

67 Structural modeling represents an alternative tool to time series that allows researchers to

68 focus on current or anticipated market conditions. Many authors, including de Gorter and Just

69 [17-19], Keeney and Hertel [20] and Tyner et al. [21], use structural models to study some of the

70 consequences of policy on energy and agricultural markets. For example, Elobeid and Tokgoz

71 [22] trace out the impact of removing the U.S. tax credit on ethanol markets using a multimarket 
72 international ethanol model that consists of U.S., Brazil, and ROW (Rest of the World).

73 Christensen and Siddiqui [23] pointed out the consequences of RFS implementation in the U.S.

74 and world ethanol markets. However, RFS sub-mandates are not considered in many past studies.

75 Many studies also represent aggregate demand for ethanol, without regard to the specific fuel

76 choices that consumers make. Meyer and Thompson [24] and Whistance et al. [25, 26] examine

77 several alternative mandate scenarios concerning the RFS sub-mandates and take into account

78 relative prices of E10 and E85. These studies estimate that certain waiver scenarios that limit U.S.

79 RFS expansion would result in a significant increase in the import of sugarcane-based ethanol, for

80 example. To the best of our knowledge, studies do not consider the consequences for world

81 ethanol markets of various options to waive the overall mandate and its components, identify

82 sensitivity with respect to the petroleum price, and take into account the complexities of demand

83 and mandate compliance.

84 We focus on (i) modeling the alternating complementary or substituting relationship

85 between ethanol and gasoline simultaneously, (ii) waiver options for various RFS components

86 that are currently under debate, and (iii) alternative future petroleum price levels. We use a

87 structural economic model to consider the use of ethanol as a complement to gasoline in E10 and

88 substitute at higher blends. Ethanol use in the U.S. and other key producing and consuming

89 countries or regions, including Brazil is represented as elastic at a higher gasoline price relative to

90 ethanol price to represent the dominance of the substitute effect and inelastic at a lower gasoline

91 price relative to ethanol price to allow for a greater role of the complementary effect. The

92 consequence is a non-linear, kinked ethanol demand curve with the petroleum price determining

93 the location of the kink (Fig. 3). This representation of ethanol demand is part of a larger global

94 partial equilibrium model of ethanol, ethanol feedstock, and related markets, including 
agricultural commodity markets to represent additional complications such as slow adjustments to area allocation or livestock numbers that can also influence responses. This model builds on similar research using structural models by applying the ideas about ethanol demand drawn from the time series literature to the global ethanol market. This approach allows an examination of how petroleum price levels interact with the U.S. biofuel mandates and estimation of biofuel price and RFS compliance implications related to this key indicator of global energy markets.

The objectives of this study are to estimate the consequences of a lower and higher petroleum price on (a) the U.S. and global ethanol markets and (b) the U.S. biofuel mandate compliance costs. Our study expands on an economic partial equilibrium model for the world ethanol market, and related markets, breaking out the U.S., Brazil, and other key countries or regions. We introduced a kinked ethanol demand curve to represent the possibility of either a complementary or substituting relationship between ethanol and gasoline market. We find that these demand-side effects are suppressed in certain key markets, including Brazil, because of existing policies. We also find that a combination of factors, including U.S. domestic and export demands as well as mandate implementation, cause a higher petroleum price to have strong ethanol price impacts and to eliminate most of the U.S. mandate compliance costs.

\subsection{U.S. Renewable Fuel Standard and its Implementation}

The U.S. established the RFS in 2005. Two years later, the Energy Independence and Security Act (EISA) expanded the RFS mandate [4]. Another element of the new legislation was the definition of four separate components of the mandate: total renewable fuels, advanced biofuel, biomass-based diesel, and cellulosic and agricultural waste based ("cellulosic") biofuel. The EISA nests some of these components as sub-mandates to others (Fig. 4). The total requirement is comprised of two categories: the sub-mandate for advanced biofuels and the 
118 remaining "conventional" gap, most of which has been met with corn starch (i.e., "conventional")

119 ethanol. The advanced biofuel mandate has two sub-mandates of its own, namely the cellulosic

120 biofuel and biomass-based biodiesel mandates, but can also be met by other advanced biofuels.

121 Equation 1 shows that the advanced gap is the portion of the advanced biofuel mandate that can

122 be met using biofuels other than biomass-based diesel or cellulosic biofuel. The advanced gap can

123 be defined in terms of other EISA mandates as:

124

$$
\mathrm{O}=\mathrm{A}-\mathrm{C}-\mathrm{B}
$$

125 where $\mathrm{O}$ is the other advanced gap biofuel, $\mathrm{A}$ is the advanced renewable biofuel mandate, $\mathrm{C}$ is the 126 cellulosic biofuel mandate, and B is the biomass-based biodiesel mandate in ethanol-equivalent 127 gallons.

The RFS mandates, as laid out in EISA, call for the use of at least 36 billion gallons (136.3

129 billion liters) of total renewable biofuel by 2022, of which up to 15 billion gallons (57.8 billion

130 liters) can be met using conventional ethanol from 2015 onwards. EISA also calls for the use of at 131 least 16 billion gallons (60.6 billion liters) of cellulosic biofuel by 2022 starting from 500 million 132 gallons (1.9 billion liters) of cellulosic biofuel in 2012. Biomass-based diesel is mandated to be at 133 least 1 billion gallons (3.8 billion liters) from 2012 onwards [4].

The RFS is administered by the U.S. Environmental Protection Agency (EPA). The EPA

135 has the responsibility to waive the RFS renewable fuel mandates, subject to criteria outlined in the 136 law that generally relates to available supplies or market impacts in some way [24]. The EPA has 137 reduced the cellulosic biofuel mandate every year at the time of writing. The hierarchy of sub138 mandates suggests that a reduction in the cellulosic biofuel volume could necessitate greater use 139 of other biofuels so that broader mandates can still be filled. For example, if only the cellulosic 140 mandate was reduced, as in 2010-2013, then the use of biodiesel or other advanced biofuels 
141 would have to offset the shortfall in cellulosic biofuel in order to comply with the advanced

142 mandate. The EISA allows for the broader mandates to be reduced if the cellulosic mandate is

143 waived, so other choices are possible. If cellulosic mandates continue to be waived in the future,

144 then there could be offsetting increases in other biofuels to meet the mandate or not, depending on 145 mandate implementation.

146 In May of 2016, the EPA released their proposed rules for 2017 [4]. The EPA used their 147 cellulosic waiver authority to reduce the overall, advanced and cellulosic mandates below the 148 original EISA levels. The 2017 requirements included some measure of growth relative to the 149 final rules for 2016, but not at the same pace as EISA suggested. The proposed overall 150 requirement rose from 18.1 billion gallons (68.5 billion liters) in 2016 to 18.8 billion gallons (71.2 151 billion liters) in 2017. Conventional ethanol in 2017 could account for 14.4 billion gallons (54.5 152 billion liters). Given the estimates of motor fuel use that were used, in part, to determine the 153 proposed volumes, these requirements do not push much past the blend wall (i.e. the amount of 154 fuel ethanol that can be consumed in $10 \%$ blends). The EPA also set the biomass-based diesel 155 requirement to rise, starting from the actual use of 1.9 billion gallons (7.2 billion liters) in 2017 156 and climbing by 0.2 billion gallons ( 0.8 billion liters) per year to reach 2.1 billion gallons (7.9 157 billion liters) in 2018.

158 The EPA sets the requirements for each year as percentages of estimated fuel use. All 159 obligated parties must demonstrate compliance by submitting a number of Renewable 160 Identification Numbers (RINs) equal to those percentages multiplied by the volume of the fuels 161 that they supply for domestic use. RINs are unique identifiers attached to each gallon of eligible 162 renewable fuel as it is produced or imported. When that fuel has been blended with petroleum fuel 
163 to be sold into the U.S. motor fuel market, those RINs can be separated and then bought, sold, or 164 traded among obligated parties.

165 In theory, RIN prices reflect the degree to which the mandates are binding, as well as the 166 hierarchical nature of mandates [13]. The petroleum price can affect RIN prices, setting aside for 167 the moment the complications of ethanol demand (Fig. 5). The increase in crude oil price has the 168 following consequences. First, overall motor fuel use in the U.S. decreases, so the product of the 169 percentage and total motor fuel use also falls so the volume of biofuel required falls (mandate

170 shift from $M_{E}$ to $M_{E}^{\prime}$ ). Second, there will be an increase in ethanol demand due to the substitution 171 effect (demand shift from $\mathrm{D}_{\mathrm{E}}$ to $\mathrm{D}^{\prime}{ }_{\mathrm{E}}$ ). This interaction can transform the RFS from binding to 172 non-binding $\left(\mathrm{Q}_{\mathrm{E}}\right.$ to $\left.\mathrm{Q}_{\mathrm{E}}{ }_{\mathrm{E}}\right)$ under certain circumstances and the given $\mathrm{RIN}$ price can fall to zero 173 (from $\mathrm{RIN}_{\mathrm{E}}$ to $\mathrm{RIN}^{\prime}{ }_{\mathrm{E}}$ ).

In 2014 , the average ethanol inclusion rate in gasoline was $9.8 \%$, which suggests that U.S.

175 domestic ethanol consumption was approaching the blend wall [27]. In order to achieve the 176 proposed higher mandates, more ethanol has to be used in high-blend fuels (e.g., E85) or through

177 increased use of drop-in fuels that are not subject to blend limits. Unlike Brazil, where high-blend 178 fuel infrastructure is more prevalent, E85 is available only at 2,677, or roughly $2.5 \%$ of, public 179 gas stations in the U.S. so not all flex-fuel owners have the choice to fill their tank with E85 [28, 180 29]. Furthermore, in areas with access to E85, the fuel often is not priced competitively on an 181 energy equivalent basis with E10, which makes it less likely to be used by flex-fuel vehicle 182 drivers when they are given the choice [30].

\section{International Ethanol Model}

The starting point is a multi-market, multi-region, partial equilibrium model that has been 185 used in some form for RFS and biofuel market analysis in the past [24, 31-33]. The U.S. biofuel 
model has been described elsewhere [24-26, 30,33,34]. For this study, we develop an explicit international ethanol model ${ }^{1}$ [35-37]. Igos et al. [38], and Cai at al. [39] use a similar model to analyze the impact of energy policy. The major ethanol producing and consuming countries are modeled, including the U.S., Brazil, Argentina, Canada, E.U., and the aggregated rest of the world (ROW), which includes China, India, and other countries. Yu and Tao [40] mentioned that fuel ethanol is becoming an important component of China's strategy for diversifying their domestic energy mix and in alleviating environmental impacts of an expanding transportation sector. In our study, Chinese ethanol production, consumption, and trade are included in the ROW. In the case of Brazil and ROW, domestic use of ethanol is modeled as the sum of inelastic low-blend fuel (complement) and elastic high-blend fuel (substitute) use $[15,16]$. The use of high-blend fuel is assumed to respond positively to increases in crude oil price. At high oil prices, we assume that there is still scope for expansion in overall use even though some part of highblend fuel use will be in places where the low-blend fuel market is saturated.

A key point is that we expect aggregate consumer demand for ethanol will be kinked, with the kink occurring near the point where the price of ethanol is equivalent to the gasoline price per unit of energy. We assume the ethanol-gasoline price ratio at which consumer demand becomes more elastic is 0.70 , which is the approximate energy equivalent level. A discount might be necessary to offset the costs of expanding the consumer and distribution infrastructure required for high-blend fuels. On the other hand, we model annual market prices aggregated over countries or even regions, so ethanol demand growth might very well expand in some places even if the ratio of broader price indices suggests otherwise. So, in general, at higher ethanol prices the ethanol demand curve is inelastic for lower blend fuels (E10) while it is elastic for higher blends (E85, E100) as the price of ethanol falls.

\footnotetext{
${ }^{1}$ Parameters used in the international ethanol model are listed in Appendix A.
} 
As we mention above, the substitution effect between hydrous ethanol (E100) and

210

211

212

213

214

215

216

217

218

219

220

221

222

223

224

225

226

227

228

229

230

231

232

233

gasoline $\mathrm{C}$ in Brazil is modeled at the level of ethanol-gasoline energy equivalence, which is about 0.70 . In addition, there is the mandate-driven anhydrous ethanol use, which is assumed to be $27 \%$ of total gasoline use over the projection period. In the case of ROW, total fuel ethanol use is modeled as a kinked demand function similar to the one shown in Fig. 3 in which two different price elasticities, one less elastic than the other, are used to drive the total fuel ethanol use. The following equations explain the domestic ethanol use in Brazil and ROW:

$Q^{E}=Q_{L}^{E}+Q_{H}^{E}$

$$
Q_{L}^{E}=\alpha-\beta\left(\frac{P_{E}}{P_{G}}\right) \quad \sigma<\left(\frac{P_{E}}{P_{G}}\right)
$$

$$
Q_{H}^{E}=\lambda-\rho\left(\frac{P_{E}}{P_{G}}\right) \quad\left(\frac{P_{E}}{P_{G}}\right) \leq \sigma
$$

where $Q^{E}$ is the total domestic ethanol use, including in lower blend, $Q_{L}^{E}$, and higher blend, $Q_{H}^{E}$, fuels. The low - and high - blend ethanol use equations represent ethanol demand based on relative prices of ethanol $\left(P_{E}\right)$ to petroleum-based gasoline $\left(P_{G}\right)$. Here, $\alpha$ and $\lambda$ are the intercepts; and $\beta$ and $\rho$ are the price coefficients for lower blend and higher blend ethanol use. Low-blend demand is less elastic or even inelastic whereas high-blend demand is expected to be elastic, or in absolute value, $\beta>\rho$. A key point is that we expect consumer demand for low - or high- blend fuels will be kinked if the price of ethanol per unit of energy is equivalent to the gasoline price. The ratio of prices at which consumers switch from fuels with no ethanol or $10 \%$ ethanol to highblend fuels is set to be at $\sigma$ (in this study it is assumed to be 0.7 ).

On the supply side, for most of the countries, ethanol production is derived by multiplying ethanol industry capacity by the utilization rate of that capacity. Both the capacity and utilization equations are driven by the lagged price of ethanol as well as the price of the feedstocks used to 
derive ethanol. We assume that, in the short term, the ethanol industry adjusts the production via the capacity utilization rate. In the longer term, we assume they are more likely to increase or decrease the overall capacity of their respective ethanol industry depending on the price of ethanol and feedstocks ${ }^{2}$. Trade equations are included for both Brazil and U.S. while ethanol trade is considered as the residual of domestic production and consumption for other countries, including ROW. We also model the stocks of ethanol as a function of ethanol price and volume of ethanol production. Table 1 summarizes the literature on the country specific gasoline and ethanol demand elasticities and ethanol supply elasticities respectively. The demand and supply elasticities of our model are listed in Table 2.

\section{Alternative Crude Oil Prices and High RFS Scenarios}

We simulate the forward-looking global biofuel markets model under high RFS and two different crude oil price scenarios. One defining trait is two alternative projections for crude oil prices based on the low and high price scenarios of the 2016 Annual Energy Outlook, which was prepared by the U.S. Energy Information Administration (EIA) [49] (Fig. 6). These alternatives do not define the ranges of possibilities, but they serve to set two very different contexts for world biofuel markets. Biofuel markets can have rebound effects on petroleum markets [34,50,51]. In this study, the rebound effects of biofuels on the gasoline market are mostly excluded.

RFS assumptions are consistent with the final RFS rules for 2014-2016 and the proposed rules for 2017. The RFS is not represented as an absolute, fixed volume in our model. Instead, the RFS is set at a percent target of total fuel use, as suggested by our reading of the EPA rules. ${ }^{3}$ In

\footnotetext{
${ }^{2}$ The functional form of the equations used in the structural economic model representing the international ethanol market are listed in Appendix B.

${ }^{3}$ Percent targets imply that the RFS volumes are determined endogenously. A high crude oil price that discourages motor fuel use would imply a low volumetric RFS requirement for a given percent requirement. However, we assume the conventional and advanced gaps in the requirement hierarchy cannot exceed the volumes implied in the EISA (i.e. the conventional gap is capped at 15 billion gallons). Under some conditions, this assumption will limit the overall and advanced volume requirements.
} 
254 both high- and low crude oil price scenarios, we assume that the overall renewable mandate in

255 U.S. will increase by 0.5 percentage points (e.g. $10.1 \%$ to $10.6 \%$ ) per year, the advanced mandate

256 will increase by 0.15 percentage points per year, the biomass-based diesel will increase by 0.1

257 percentage points per year and cellulosic biofuels will increase by 0.02 percentage points per

258 year. We map these percentages to volumes here to facilitate comparisons to other volumes,

259 including EISA levels.

260

In total, we analyze two crude oil price scenarios, high and low, under an RFS percent

261 requirement assumption that expands fairly rapidly over the simulated period. As noted above, the

262 combination of fixed percent RFS requirements and varying petroleum prices maps to a different

263 set of RFS volumes in each scenario.

264 5. Scenario Analysis and Results

Table 3 compares the projected U.S. and Brazilian ethanol and gasoline prices and U.S.

266 RIN prices obtained from solving the global biofuel model under two alternative crude oil price

267 scenarios and with the assumption of U.S. high RFS. In the low crude oil price scenario, we

268 estimate the 2023-25 average U.S. Omaha rack price to be \$0.54 per liter and the Brazilian

269 anhydrous ethanol price to be $\$ 0.53$ per liter. The estimated average retail gasoline prices in the

270 U.S. and Brazil are $\$ 0.48$ per liter and \$0.83 per liter respectively. Under the high crude oil price

271 scenario, the estimated ethanol prices for the U.S. rack and Brazil anhydrous increase to $\$ 0.62$ per

272 liter and 0.60 per liter respectively, and gasoline price is estimated to be $\$ 1.74$ per liter in the U.S.

273 and \$1.02 per liter in Brazil. The U.S. gasoline price is more sensitive to the changes in the world

274 crude oil price relative to the Brazilian gasoline price. In Brazil, the gasoline $\mathrm{C}$ price is influenced

275 by policy in addition to variations in global petroleum and petroleum product market conditions

276 and prices. This pattern is assumed to continue during the simulation period: the global crude oil 
277 price has less effect on the Brazilian gasoline C price than on the U.S. retail price. However, the

278 changes in ethanol price across both the countries are quite similar in magnitude.

With the increase in crude oil price, the U.S. RFS is not binding whereas the RFS is

280 binding in the low crude oil price case (as demonstrated in Fig. 5). The conventional RIN price

281 falls to zero in the high crude oil price scenario compared to \$0.34 per RIN-liter in the low crude

282 oil price case (Table 3). Moving from the low crude oil price scenario to the high price scenario,

283 the RIN values attached to other advanced biofuel and biomass-based diesel ${ }^{4}$ also fall to zero,

284 implying that these components of the mandate also cease to be binding.

U.S. RIN generation under the two alternative crude oil prices is shown in Table 4. The substitution effect under the high crude oil price scenario drives an increase in both the ethanol

287 demand, which leads to an increase in conventional RINs generation from 15 to 19.1 billion RINs. The RINs generated from other advanced biofuel decrease from 0.9 billion RINs to 0.5 billion RINs, while the RINs generated from biomass-based diesel and cellulosic biofuel remain flat between the low and high crude oil prices scenarios. The main reason behind the decrease in the number of other advanced biofuel RINs is the decrease in the total volume of the corresponding mandate requirements even though the percentage requirements remain identical in both cases. With the decrease in total mandated volumes from the low crude oil price scenario to 294 the high crude oil price scenario, the use of RINs for overall RFS compliance in the U.S. decreases from 21.7 billion RINs to 16.4 billion RINs.

Table 5 shows the differences in domestic production, fuel use and net trade of ethanol by 297 major ethanol producing and consuming countries between the low crude oil price and high crude 298 oil price scenarios under the U.S. high RFS mandate assumption. The increasing crude oil price

\footnotetext{
${ }^{4}$ The model represents all components of the mandate and the related biofuel markets. However, the focus of this study is on ethanol markets, not biomass-based diesel.
} 
drives higher consumer demand for ethanol, although the degree of the impact can vary widely among countries depending on the level of use relative to the blend wall. Higher consumer demand causes an increase in the ethanol price (Table 3) which, in turn, leads to an increase in ethanol production worldwide (Table 5). In Brazil, ethanol consumption increases by $2.7 \%$ in the high crude oil price case relative to the low crude oil price case. This is less than expected given that the availability of hydrous ethanol (E100) at the retail level implies consumers can quickly switch between petroleum-based fuel and ethanol depending on the relative prices (Fig. 2). However, the results are consistent with the assumption that the Brazilian gasoline price is controlled, in part, by policy. The increase in ethanol production leads to an increase in the Brazilian net ethanol exports by around 2.2 billion liters.

Comparing the low crude oil price to the high crude oil price scenario, ROW ethanol production increases by 95 million liters while consumption increases by 5.7 billion liters. These changes lead to an increase in net imports by 5.5 billion liters from the international market. ROW production and consumption response are uncertain given the array of countries and regions represented, but it is possible that rising petroleum prices increase ethanol demand in countries that have not played a large role in the world ethanol market in the past and that these countries consequently increase imports, at least over a medium-term projection.

In the U.S., the high crude oil prices, and subsequently high gasoline prices, increase the domestic fuel ethanol use by $25.2 \%$ and production by $29.5 \%$ (Table 5). The results in table 5 show that, regardless of the crude oil price level, the U.S. is a major exporter of ethanol to the world market. However, with a high crude oil price both the U.S. and Brazil see an expansion in their net exports to the global ethanol market. 
The per capita simulated ROW ethanol use over the projection period is shown in Fig. 7.

322 In the case of a low crude oil price path, ethanol demand might be expected to be inelastic.

323 Demand for ethanol as a substitute would be low; the marginal use would often be as a

324 complement - unless the policy of a particular country or jurisdiction requires greater use beyond

325 the blend wall. The per capita ethanol use is expected to be very elastic when the crude oil price is

$326 \$ 220$ per barrel. The demands traced out by our simulation results are consistent across low and

327 high crude oil prices and ROW (Fig. 7) and are conceivably extensions of recent data (Figs. 1 and

328 2). The time series effects of the net ethanol trade among the major ethanol importing and

329 exporting countries are traced in Fig. 8, which shows that with the increase in crude oil price (Fig.

330 6) the consumption in ROW increases resulting in increasing imports, mostly from the U.S and

331 Brazil.

$332 \quad 5.1 \quad$ Sensitivity to RFS waiver

333 The responsiveness of ethanol use in the U.S. depends in part on the mandates. We assume a

334 fairly constant percent requirement, as suggested by recent implementation decisions. However, it

335 might be the case that the RFS targets are also adjusted. To test the sensitivity of results to the

336 mandate, we test the impacts of a reduction in the mandate in the low crude oil price case. Relaxing the mandate in the low crude oil price case allows the conventional RIN price to

338 fall, dropping by less than a third in this experiment. Domestic ethanol use in the U.S. contracts, 339 as expected, given the combination of weak demand for ethanol as a substitute, beyond the blend 340 wall, and less required use to satisfy policy requirements. Of the 1.5 billion liters less domestic 341 use in this experiment, about half is exported, with reduced U.S. ethanol production accounting 342 for the other half. Greater U.S. ethanol exports tend to displace Brazilian exports in the low crude 343 oil price case, with global ethanol demand mostly inelastic. 
This experiment shows that results can be sensitive to the mandate. The potential for U.S. to respond to changes in world ethanol market conditions caused by crude oil price changes can vary if the mandate is set more or less aggressively. Moreover, results suggest that, because of their competition in international markets and particularly in the context of inelastic global ethanol demand, changes in U.S. ethanol trade tend to cause offsetting effects in Brazilian trade.

\section{Conclusions and Policy Implications}

Whereas scientific assessment of how petroleum price and the RFS interact does not consistently exploit information about current and future ethanol demand, we develop a representation that allows us to explore the interaction of petroleum prices and the RFS in a forward-looking context that reflects the current realities of global ethanol markets. Our work is important for policy makers who decide the future of the RFS, regulators who implement these mandates, and to industry, public, and scientific communities because of the relationship to compliance costs and broader implications relating to market effects, food security, and GHGs. Studies based on historical price data or a historical base period might relate to a time of rising RFS biofuel use that was still below the blend wall in the U.S. or might not take into account the potential for similar non-linear ethanol demand responses in other countries. The findings of this study are critical as, with the U.S. E10 market saturated and the future crude oil price a source of great uncertainty, the potential interactions of future RFS implementation and ethanol demand, in the U.S. and elsewhere, the potential mandate impacts are unknown to policymakers, regulators, industry representatives, and others.

In this paper, a structural economic model of biofuel and related markets is expanded and used to estimate the impacts of crude oil prices taking into account U.S. biofuel mandates and the varying nature of the gasoline-ethanol relationship. We exploit a widely used structural model 
367 ([24-26, 30, 33, 34, 52] and develop further the representation of ethanol demand to reflect new368 found complications in demand that indicate the potential for a regime change between 369 complementary and substituting relationships ([12,13], Figs. 1 and 2). The RFS is represented 370 based on how it is implemented now, namely as slowly rising percentage of total U.S. fuel use, 371 rather than as fixed volume targets. The petroleum price can have complicated effects through (a)

372 the overall level of fuel demand in the U.S. and consequently the effective mandate as 373 implemented, (b) the demand for ethanol based on relative fuel prices in the U.S., and (c) world 374 demand for ethanol to the extent that the marginal use is as a substitute for petroleum products. 375 As historical data can represent a different market structure, we believe that forward-looking 376 analysis of these complicated petroleum price effects requires a structural model of the type we 377 apply here.

378 We find that a crude oil price of around $\$ 50$ per barrel implies a market condition in which 379 ethanol use is often complementary to gasoline, with only limited substitution potential at the 380 margin. The lower and less elastic ethanol demand leads to more binding U.S. mandates and 381 lower U.S. exports but also depressed global ethanol trade more generally. In contrast, a crude oil 382 price of around $\$ 220$ per barrel - a level that is consistent with EIA high crude oil price projection 383 - implies a very different setting for global ethanol markets. This high crude oil price implies far 384 more potential to substitute from gasoline to ethanol globally and greater global trade. Moreover, 385 this high price level depresses total U.S. fuel demand, so the U.S. mandate percentage is mapped 386 to a lower absolute level and is more easily filled. Global ethanol trade can become lively if crude 387 oil prices recover to their old levels and keep rising from there. That said, we find important 388 distinctions between responses in countries where the changing relative prices can move ethanol 
demand into a substituting relationship as compared to countries, such as the U.S. and Brazil, where demand is tied to mandates or is at some limit, like the blend wall.

Our research also raises certain concerns that might be addressed in other studies. If the blend wall proves a persistent barrier to domestic ethanol use, then researchers who investigate the RFS might add information by recognizing two different contexts, namely the complementary or substituting relationship between gasoline and ethanol at the margin. Studies of how mandate implementation affects the domestic market, and imports and exports of the U.S., as well as the effects in Brazil and other parts of the world, might be quite sensitive to the exact crude oil price path. The nature of global ethanol demand is uncertain and research is scarce on what could be an increasingly important issue for biofuel producers, biofuel and climate change mitigation policies, and by agricultural producers that provide the inputs to biofuel markets. The potential for nonlinear ethanol demand and asymmetric responses that vary with petroleum price have serious implications. As shown here, mandate compliance costs can vary with market conditions, implying that the costs of any results of the RFS pertaining to GHG reduction targets or energy security, with consequences for any cost-benefit assessment of this policy. Scientific assessments of the ethanol market or supply chains ([24-26, 30, 33, 34, 52]) or environmental impacts ([5355]) might generate results that are specific at a certain petroleum price or a particular point in time historically, with limited ability for extrapolation to current or future market conditions. Our work supports greater efforts by researchers to confirm results for different market contexts and different segments of ethanol demand. We also caution readers who would apply findings of past ethanol studies to verify that the ethanol demand representation of a simulation model or the nature of demand during a historical estimation period is a realistic representation of ethanol 
411 demand response at the time relevant to the decisions of policy makers, regulators, investors, or

412 others whom researchers wish to inform.

413 Acknowledgements

414 This study is supported by U.S. Department of Agriculture grants under Agreement Nos.

415 58-0111-15-008, 58-0111-16-011, and the USDA National Institute of Food and Agriculture,

416 Hatch project number MO- HASS0024. Any opinion, findings, conclusions, or recommendations

417 expressed in this publication are those of the authors and do not necessarily reflect the view of the

418 U.S. Department of Agriculture nor the University of Missouri. We also thank anonymous

419 reviewers and the editor-in-chief for their suggestions that improved the technical details and

420 clarity of this paper.

421

422

423 
424

425

426

427

428

429

430

431

432

433

434

435

436

437

438

439

440

441

442

443

444

445

446

447

\section{References}

[1] REN21. Renewables 2016 global status report. Paris France, 2016. http://www.ren21.net/wp-content/uploads/2016/06/GSR_2016_Full_Report.pdf.

[2] Damirbas A. Competitive liquid biofuels from biomass. Appl Energy 2011;88:17-28. doi:10.1016/j.apenergy.2010.07.016.

[3] Balat M, Balat H. Recent trends in global production and utilization of bio-ethanol fuel. Appl Energy 2009;86:2273-2282. doi:10.1016/j.apenergy.2009.03.015.

[4] U.S. EPA. Renewable Fuel Standard Program. Retrieved from <https://www.epa.gov/renewable-fuel-standard-program>.

[5] Tan RR, Aviso KB, Barilea IU, Culaba AB, Cruz Jr JB. A fuzzy multi-regional input-output optimization model for biomass production and trade under resource and footprint constraints. Appl Energy 2012;90:154-160. doi:10.1016/j.apenergy.2011.01.032.

[6] Jonker JGG, Junginger HM, Verstegen JA, Lin T, Rodríguez LF, Ting KC, Faaij APC, van der Hilst F. Supply chain optimization of sugarcane first generation and eucalyptus second generation ethanol production in Brazil. Appl Energy 2016;173:494-510. doi:10.1016/j.apenergy.2016.04.069.

[7] Rendon-Sagardi MA, Sanchez-Ramirez C, Cortes-Robles G, Alor-Hernandez G, CedilloCampos MG. Dynamic analysis of feasibility in ethanol supply chain for biofuel production in Mexico. Appl Energy 2014;123:358-367.

[8] Zhang D, Asche F, Oglend A. An analysis of price transmission in the US market. Energy Econ 2014;42:1-8. doi:10.1016/j.eneco.2013.11.012.

[9] Serra T, Zilberman D. Biofuel-related price transmission literature: A review. Energy Econ 2013;37:141-151. doi:10.1016/j.eneco.2013.02.014. 
448 [10] Serra T, Zilberman D, Gil J. Price volatility in ethanol markets. Eur Rev Agric Econ 2011;38:259-280. doi:10.1093/erae/jbq046.

450 451

452 453 454 455 456

457 458 459 460 461 462 463

464 465 466 467 468

[11] Serra T, Zilberman D, Gil JM, Goodwin BK. Nonlinearities in the U.S. corn-ethanol-oilgasoline price system. Agric Econ 2011;42:35-45. doi:10.1111/j.1574-0862.2010.00464.x.

[12] Whistance J, Ripplinger D, Thompson W. Biofuel-related price transmission using Renewable Identification Number prices to signal mandate regime. Energy Econ 2016;55:19-29. doi:10.1016/j.eneco.2015.12.026.

[13] Whistance J, Thompson W. A critical assessment of RIN price behavior and the implications for corn, ethanol, and gasoline price relationships. Appl Econ Perspect Policy 2014;36:623642. doi:10.1093/aepp/ppu012.

[14] Zhang Z, Lohr L, Escalante C, Wetzstein M. Food versus fuel: What do prices tell us? Energy Policy 2010;38:445-451. doi:10.1016/j.enpol.2009.09.034.

[15] Demirbas A. Political, economic and environmental impacts of biofuel: A review. Appl Energy 2009;86:S108-S117. doi:10.1016/j.apenergy.2009.04.036.

[16] Szklo A, Schaeffer R, Delgado F. Can one say ethanol is a real threat to gasoline? Energy Policy 2007;35:5411-5421. doi:10.1016/j.enpol.2007.07.017.

[17] de Gorter H, Just DR. The economics of a blend mandate for biofuels. Am J Agric Econ 2009;91:738-750. doi:10.1111/j.1467-8276.2009.01275.x.

[18] de Gorter H, Just DR. The welfare economics of a biofuel tax credit and the interaction effects with price contingent farm subsidies. Am J Agric Econ 2009;91:477-488. doi:10.1111/j.1467-8276.2008.01190.x. 
[19] de Gorter H, Just DR. The social costs and benefits of biofuels: the intersection of environmental, energy and agricultural policy. Appl Econ Perspect Policy 2010;32:4-32. doi:10.1093/aepp/ppp010.

[20] Keeney R, Hertel TW. The indirect land use impacts of United States biofuel policies: The importance of acreage, yield, and bilateral trade responses. Am J Agric Econ 2009;91:895909. doi:10.1111/j.1467-8276.2009.01308.x.

[21] Tyner WE, Taheripour F, Perkis D. Comparison of fixed versus variable biofuels incentives. Energy Policy 2010;38:5530-5540. doi:10.1016/j.enpol.2010.04.052.

[22] Elobeid A, Tokgoz S. Removing distortions in the US ethanol market: What does it imply for the United States and Brazil? Am J Agric Econ 2008;90:918-932.

[23] Christensen A, Siddiqui S. Fuel price impacts and compliance costs associated with the Renewable Fuel Standard (RFS). Energy Policy 2015;86:614-624. doi:10.1016/j.enpol.2015.08.002.

[24] Meyer S, Thompson W. How do biofuel use mandates cause uncertainty? United States environmental protection agency cellulosic waiver options. Appl Econ Perspect Policy 2012;34:570-586. doi:10.1093/aepp/pps033.

[25] Whistance J, Meyer S, Thompson W. Renewable fuel standard waiver options for 2014 and beyond. FAPRI-MU Report \#07-13. FAPRI: University of Missouri - Columbia; 2013.

[26] Whistance J, Thompson W, Meyer S. Biomass-based diesel policy options: larger RFS requirements and tax credit extension. FAPRI-MU Report \#01-14. FAPRI: University of Missouri - Columbia; 2014.

[27] U.S. Energy Information Administration (EIA) Retrieved from <http://www.eia.gov/>. 
[28] EERE: Alternative Fuels Data Center Home Page. Retrieved from $<$ http://www.afdc.energy.gov/>.

[29] Industries at a Glance: Gasoline Stations: NAICS 447. Retrieved from <http://www.bls.gov/iag/tgs/iag447.htm>.

[30] Whistance J, Thompson W, Westhoff P, others. Are RIN prices high enough for E85 expansion? FAPRI-MU Bulletin \#01-15. FAPRI: University of Missouri - Columbia; 2015.

[31] Barr KJ, Babcock BA, Carriquiry MA, Nassar AM, Harfuch L. Agricultural land elasticities in the United States and Brazil. Appl Econ Perspect Policy 2011;33:449-462. doi:10.1093/aepp/ppr011.

[32] Dumortier J, Hayes DJ, Carriquiry M, Dong F, Du X, Elobeid A, et al. Sensitivity of carbon emission estimates from indirect land-use change. Appl Econ Perspect Policy 2011;33:428448. doi:10.1093/aepp/ppr015.

[33] Egbendewe-Mondzozo A, Swinton SM, Kang S, Post WM, Binfield JC, Thompson W. Bioenergy supply and environmental impacts on cropland: Insights from multi-market forecasts in a great lakes subregional bioeconomic model. Appl Econ Perspect Policy 2015;37:602-618. doi:10.1093/aepp/ppu044.

[34] Thompson W, Whistance J, Meyer S. Effects of US biofuel policies on US and world petroleum product markets with consequences for greenhouse gas emissions. Energy Policy 2011;39:5509-5518. doi:10.1016/j.enpol.2011.05.011.

[35] Debnath D, Thompson W, Whistance J. The causes of two-way U.S.-Brazil ethanol trade and the consequences for greenhouse gas emissions. In Agricultural \& Applied Economics Association Annual Meeting; 2016, Boston, USA. http://ageconsearch.umn.edu/bitstream/235824/2/CausesOfTwoWayTrade-DRAFT.pdf 
514 [36] Debnath D, Binfield J, Whistance J, Westhoff P, Thompson W. International biofuels

515 baseline briefing book. FAPRI-MU Report \#03-16. FAPRI: University of Missouri -

$516 \quad$ Columbia; 2016.

517 [37] Debnath D, Binfield J, Whistance J. Impacts of U.S. biofuel mandate waiver on world 518 ethanol and biodiesel market. In Agricultural \& Applied Economics Association Annual 519 Meeting; 2014, Minneapolis, USA. 520 http://ageconsearch.umn.edu/bitstream/173301/2/AAEA_Biofuels_2014.pdf

521 [38] Igos E, Rugani B, Rege S, Benetto E, Drouet L, Zachary DS. Combination of equilibrium 522

[39] Cai Y, Newth D, Finnigan J, Gunasekera D. A hybrid energy-economy model for global integrated assessment of climate change, carbon mitigation and energy transformation. Appl Energy 2015;148:381-95. doi:10.1016/j.apenergy.2015.03.106.

[40] Yu S, Tao J. Economic, energy and environmental evaluations of biomass-based fuel ethanol projects based on life cycle assessment and simulation. Appl Enegry 2009;86:S178S188. doi:10.1016/j.apenergy.2009.04.016

[41] Tokgoz S. January 2009. The impact of energy markets on the EU agricultural sector. CARD Working Paper 09-WP 485; CARD: Iowa State University, Ames, Iowa; 2009. http://ageconsearch.umn.edu/bitstream/47051/2/09-WP_485.Tokgoz.pdf.

[42] Anderson ST. The demand for ethanol as a gasoline substitute. J Environ Econ and Manag 2012;63:151-168. doi:10.1016/j.jeem.2011.08.002. 
[43] Santos AI, Marcelo C. The elasticity of demand for gasoline in Brazil with the introduction of the flex-fuel fleet. In: $37^{\text {th }}$ IAEE International Conference; 2014, New York City, USA. http://www.usaee.org/usaee2014/submissions/OnlineProceedings/3716-Paper.pdf.

[44] Golub A, Hertel TW, Taheripour F, Tyner WE. Modeling biofuels policies in general equilibrium: insights, pitfalls, and opportunities. In: New developments in computable general equilibrium analysis for trade policy (frontiers of economics and globalization, volume 7), vol. 7. Emerald Group Publishing Limited; 2010. p. 153-187.

[45] Sukati MA. The effects of the EC ethanol blend mandate on the EU/Global sugar Market and its implications on sugar trade with ACP countries. In $13^{\text {th }}$ Annual Conference on Global Economic Analysis; 2010, Penang, Malaysia. https://www.gtap.agecon.purdue.edu/resources/download/4684.pdf.

[46] Jianping GE, Yalin LEI. Assessing welfare and growth effects of grain-based fuel ethanol development in China: A general equilibrium framework. J Conver Inf Technol 2010;5(10):1-8. doi:10.4156/jcit.vol5. issue10.1.

[47] Chisari OO, Romero, CA, Timilsina G. Potential gains and losses of biofuel production in Argentina a computable general equilibrium analysis. The World Bank Development Research Group Environment and Energy Team Policy Research Working Paper WPS6124; 2012. http://elibrary.worldbank.org/doi/abs/10.1596/1813-9450-6124.

[48] Santos GF. Fuel demand in Brazil in a dynamic panel data approach. Energy Econ 2013;36:229-240. doi:10.1016/j.eneco.2012.08.012.

[49] U.S. Energy Information Administration. Annual Energy Outlook. 2016. Retrieved from $<$ http://www.eia.gov/outlooks/aeo/>. 
559 [50] Chen X, Huang H, Khanna M. Land-use and greenhouse gas implications of biofuels: role of 560 technology and policy. Clim Change Econ 2012;3:1-25. doi:10.1142/S2010007812500133.

561 [51] Rajagopal D, Plevin R, Hochman G, Zilberman D. Multi-objective regulations on

562 transportation fuels: Comparing renewable fuel mandates and emission standards. Energy

$563 \quad$ Econ 2015;49:359-69. doi:10.1016/j.eneco.2015.02.020.

564 [52] Enciso SRA, Fellmann T, Dominguez IP, Santini F. Abolishing biofuel policies: Possible 565 566 567 impacts on agricultural price levels, price variability and global food security, Food Policy 2016;61: 9-26. doi:10.1016/j.foodpol.2016.01.007.

[53] Xu Z., Tian-yu Q., Xun-min O., Xi-liang Z. The role of multi-region integrated emissions trading scheme: A computable general equilibrium analysis. Appl Energy 2017;185:1860-68. doi:10.1016/j.apenergy.2015.11.092.

[54] Carvalho A, Antunes C, Freire F. Economic-energy-environment analysis of prospective sugarcane bioethanol production in Brazil. Appl Energy 2016;181:514-526. doi:10.1016/j.apenergy.2016.07.122.

[55] Ziolkowska J. Optimizing biofuels production in an uncertain decision environment Conventional vs. advanced technologies. Appl Energy 2014;114:366-376. doi:10.1016/j.apenergy.2013.09.060.

[56] Nebraska Energy Office. 2015. Retrieved from < http://www.neo.ne.gov/statshtml/66.html $>$. [57] Oil Price Information Service. 2015. Biofuels News Alerts. (Various Issues).

[58] Bureau of Labor Statistics. 2015. Retrieved from <http:// http:// https://www.bls.gov/data/>.

[59] National Agency of Petroleum, Natural Gas and Biofuels. Sales of fuel ethanol by Suppliers. 2015. Retrieved from < http://www.anp.gov.br/wwwanp/dados-estatisticos $>$. 
583 [60] National Agency of Petroleum, Natural Gas and Biofuels. Pricing Summary - Brazil. 2015. Retrieved from <http://www.anp.gov.br/preco/prc/Resumo_Semanal_Index.asp>. 
Table 1. Summary of published country specific ethanol and gasoline demand and supply elasticities.

\begin{tabular}{|c|c|c|c|c|c|c|}
\hline \multirow{2}{*}{$\begin{array}{l}\text { Previous Study } \\
\text { Authors }\end{array}$} & \multirow[b]{2}{*}{ Ref. } & \multicolumn{4}{|c|}{ Elasticities } & \multirow[b]{2}{*}{ Income } \\
\hline & & Country & Commodity & Own Price & Cross Price & \\
\hline \multicolumn{7}{|l|}{ Demand side } \\
\hline \multirow[t]{3}{*}{ Elobeid and Tokgoz } & {$[22]$} & U.S. & $\begin{array}{l}\text { Ethanol } \\
\text { Anhydrous }\end{array}$ & -0.43 & & 0.11 \\
\hline & & Brazil & Ethanol & -0.10 & & 0.13 \\
\hline & & Brazil & Hydrous Ethanol & -0.30 & & 0.13 \\
\hline \multirow[t]{2}{*}{ Tokgoz } & [41] & E.U. & Ethanol & -0.55 & 0.51 & \\
\hline & & & Gasoline & -0.77 & & 0.10 \\
\hline Anderson & {$[42]$} & U.S. & Ethanol & & 2.50 to 3.00 & \\
\hline Santos and Colomer & [43] & Brazil & Ethanol & -0.48 & 1.42 & \\
\hline \multirow[t]{3}{*}{ Golub et al. } & [44] & Brazil & Biofuels & & 1.35 & \\
\hline & & E.U. & Biofuels & & 1.65 & \\
\hline & & U.S. & Biofuels & & 3.95 & \\
\hline Sukati & {$[45]$} & E.U. & Ethanol & -0.03 to -0.06 & & \\
\hline Jianping and Yalin & {$[46]$} & China & Ethanol & & 0.10 to 5.00 & \\
\hline Chisari et al. & {$[47]$} & Argentina & Biofuels & & 2.00 & \\
\hline \multirow[t]{2}{*}{ Santos } & {$[48]$} & Brazil & Gasoline & -0.78 & 1.56 & 0.28 \\
\hline & & & Ethanol & -1.53 & 1.18 & 0.54 \\
\hline \multicolumn{7}{|l|}{ Supply side } \\
\hline \multirow[t]{2}{*}{ Elobeid and Tokgoz } & {$[22]$} & U.S. & Ethanol & 0.65 & & \\
\hline & & Brazil & Ethanol & 0.20 & & \\
\hline Tokgoz & [41] & E.U. & Ethanol & 0.79 & & \\
\hline
\end{tabular}

Source: Elasticities are drawn from referenced studies as listed above. 
Table 2. Ethanol and gasoline demand and supply elasticities used in this study

\begin{tabular}{|c|c|c|c|}
\hline Country & Commodity & Price Elasticity & $\begin{array}{l}\text { Income } \\
\text { Elasticity }\end{array}$ \\
\hline \multicolumn{4}{|c|}{ Demand Side } \\
\hline \multirow[t]{2}{*}{ U.S } & Gasoline & -0.07 & 0.11 \\
\hline & Ethanol (E10) & -5.85 & na \\
\hline \multirow[t]{2}{*}{ Brazil } & Gasoline & -0.10 & 0.30 \\
\hline & Ethanol & -0.50 & 0.10 \\
\hline \multirow[t]{2}{*}{ E.U. } & Gasoline & -0.10 & 0.50 \\
\hline & Ethanol & -0.03 & 0.30 \\
\hline Argentina & Ethanol & -0.05 & 0.10 \\
\hline Canada & Ethanol & -0.03 & 0.40 \\
\hline ROW & Ethanol & -0.20 & 0.10 \\
\hline \multicolumn{4}{|c|}{ Supply Side* } \\
\hline U.S & Ethanol & 1.13 & na \\
\hline Brazil & Ethanol & 0.80 & na \\
\hline E.U. & Ethanol & 0.10 & na \\
\hline Argentina & Ethanol & 0.20 & na \\
\hline Canada & Ethanol & 0.70 & na \\
\hline ROW & Ethanol & 0.60 & na \\
\hline
\end{tabular}

*Ethanol supply, we employ linear capacity and logistic capacity-utilization rate equations. Here, we show the percent changes in utilization rates that occur given a $1 \%$ increase in the ratio of ethanol to gasoline prices. They are not elasticities in the strictest sense, but they give the reader an idea of the responsiveness of these utilization rates.

Source: Authors' calculation. 
Table 3. Ethanol and RIN prices (\$/liter)*

\section{Low Oil Price High Oil Price}

Ethanol

U.S. Omaha Rack

$0.54 \quad 0.62$

Brazilian Anhydrous (F.O.B)

$0.53 \quad 0.60$

Gasoline Price ${ }^{* *}$

U.S.

0.48

1.74

Brazil

0.83

1.02

Renewable Identification Numbers (RIN)

Conventional 0.34

Advanced

0.34

0.00

Biomass-based Diesel

0.50

0.00

0.00

*Average of the last three years of the projection 2023-2025

**Domestic retail gasoline price

Source: Authors' calculation. 
Table 4. RIN generation in U.S. under alternative oil price scenarios (million RINs)*

\begin{tabular}{lcc}
\hline & Low Oil Price & High Oil Price \\
\hline Production & 21,759 & 25,404 \\
Total Advanced & 6,713 & 6,319 \\
Biomass-based Diesel** & 5,490 & 5,552 \\
Cellulosic & 277 & 277 \\
Other Advanced & 946 & 490 \\
Conventional & 15,046 & 19,085 \\
Use for RFS compliance** & 21,694 & 16,391 \\
\hline
\end{tabular}

* Average of the last three years of the projection (2023-2025)

** Stated in ethanol equivalent terms

Source: Authors' calculation. 
Table 5. Changes in ethanol production, fuel use and net trade by country, low and high crude oil prices (million liters)*

\begin{tabular}{lcccc}
\hline & Low Oil Price & High Oil Price & $\begin{array}{c}\text { Absolute } \\
\text { Changes }\end{array}$ & $\begin{array}{c}\text { Percentage } \\
\text { Changes }\end{array}$ \\
\hline United States & 60,079 & 77,782 & 17,703 & $29.5 \%$ \\
Production & 56,944 & 71,266 & 14,322 & $25.2 \%$ \\
Domestic Fuel Use & 1,504 & 4,803 & 3,299 & \\
Net Export & & & & \\
Brazil & 28,682 & 31,686 & 3,004 & $10.5 \%$ \\
Production & 26,089 & 26,784 & 695 & $2.7 \%$ \\
Domestic Fuel Use & 718 & 2,887 & 2,169 & \\
Net Export & & & & \\
European Union & 7,955 & 7,967 & 12 & $0.2 \%$ \\
Production & 5,236 & 5,269 & 33 & $0.6 \%$ \\
Domestic Fuel Use & 207 & 183 & -24 & $-11.6 \%$ \\
Net Export & & & & \\
Canada & 2,064 & 2,099 & 35 & $1.7 \%$ \\
Production & 2,818 & 2,823 & 5 & $0.2 \%$ \\
Domestic Fuel Use & 964 & 935 & -29 & $-3.0 \%$ \\
Net Import & & & & \\
Argentina & 1,277 & 1,279 & 2 & $0.1 \%$ \\
Production & 1,176 & 1,177 & 1 & $0.1 \%$ \\
Domestic Fuel Use & 49 & 48 & -1 & $-2.0 \%$ \\
Net Import & & & & \\
Rest of the World & 20,928 & 21,023 & 95 & $0.5 \%$ \\
Production & 8,897 & 14,599 & 5,702 & $64.1 \%$ \\
Domestic Fuel Use & 75 & 5,550 & 5,475 & \\
Net Import & & & & \\
\hline
\end{tabular}

*Average of the last three years of the projection 2023-2025.

Source: Authors' calculation.

Note: Global net trade data do not balance historically because of discrepancies in the raw data and we assume that this error is constant in the period and in both scenarios. Domestic non-fuel use is not mentioned in the table. It is assumed to be exogenous and does not change between scenarios. 


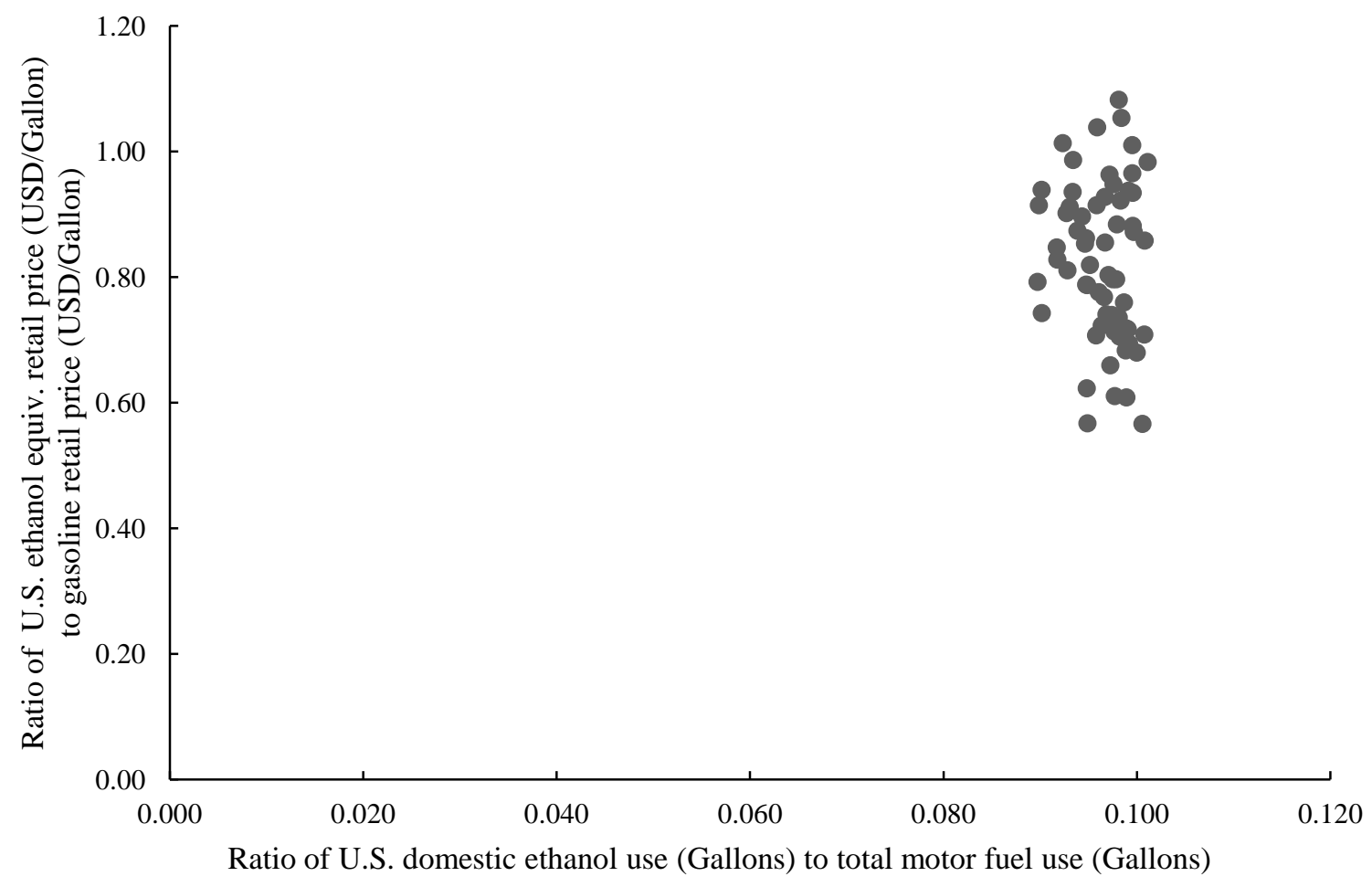

Figure 1. The ratio of the ethanol use to gasoline use plotted against the ratio of the ethanol retail price to gasoline retail price in the U.S., suggesting complementarity.

Source: Ethanol and motor fuel use data are from EIA [27]; U.S. ethanol retail price in energy equivalent terms is calculated based on Nebraska monthly ethanol price [56], assumed margins, and RIN price data from OPIS [57]; and U.S. gasoline retail price is from Consumer Price Index, Department of Labor [58].

Note: Data represent the period from January 2010 to February 2015. 


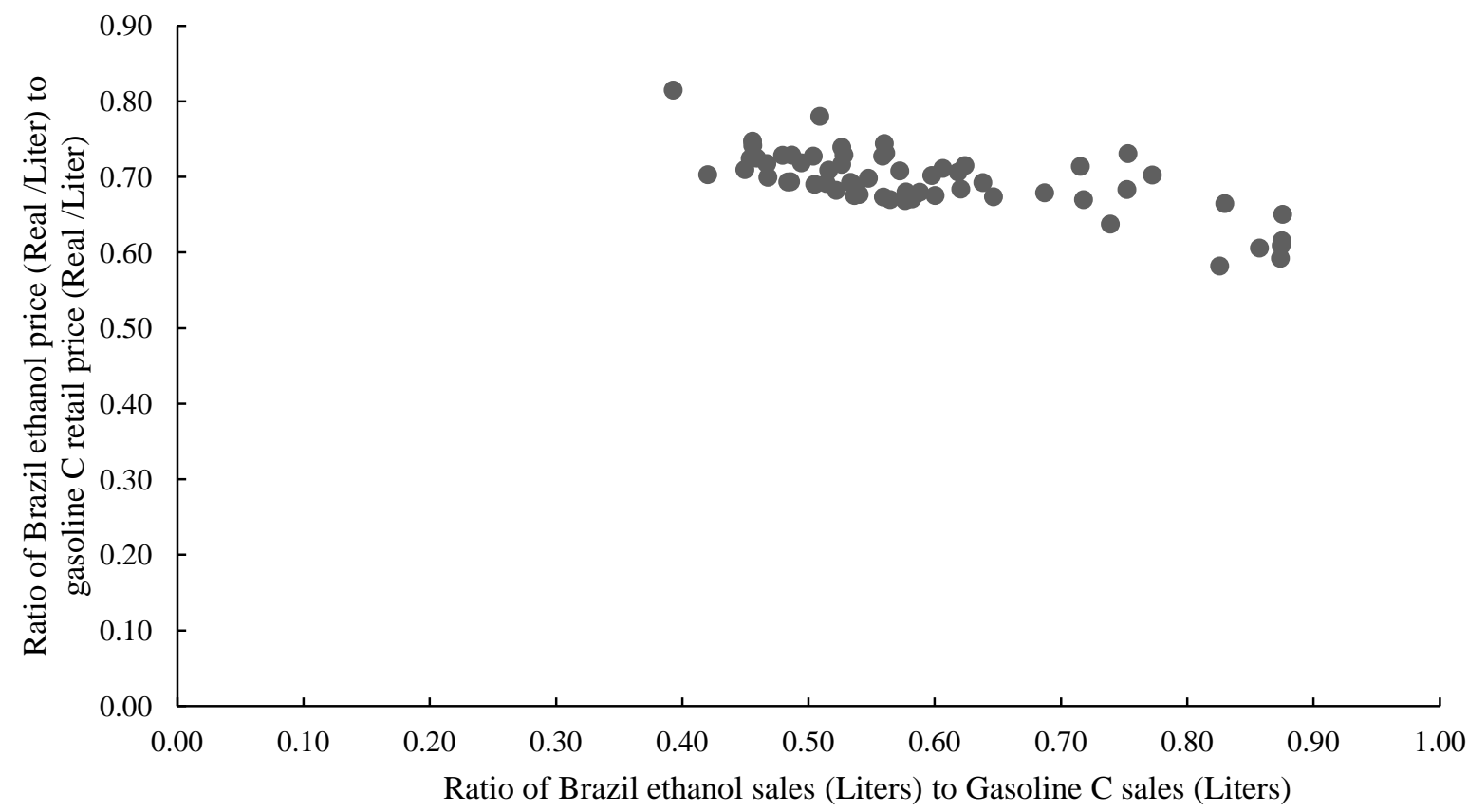

Figure 2. The ratio of ethanol and gasoline $\mathrm{C}$ sales plotted against the ratio of the ethanol retail price to gasoline $\mathrm{C}$ retail price in Brazil, suggesting substitution.

Source: Brazil ethanol and gasoline price and domestic sales data are obtained from National Agency of Petroleum, Natural Gas and Biofuels (Agência Nacional do Petróleo, Gás Natural e Biocombustíveis) [59, 60].

Note: Data represent the period from January 2010 to February 2015. 


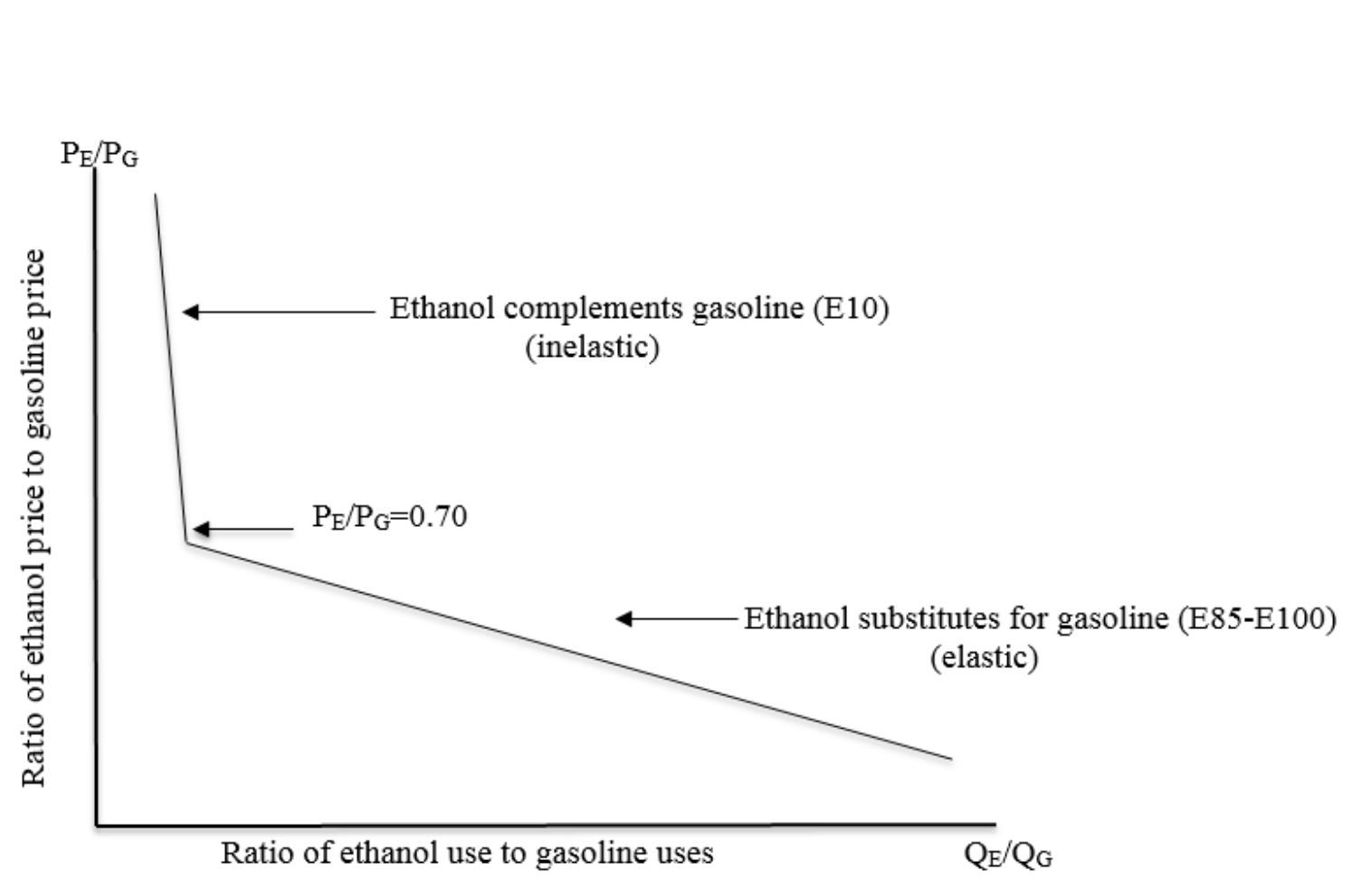

Figure 3. Kinked ethanol demand curve.

Figure 3

rige

3

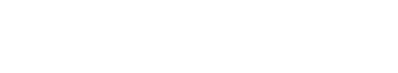

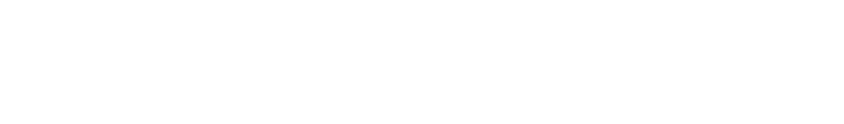

\title{
Figure
}

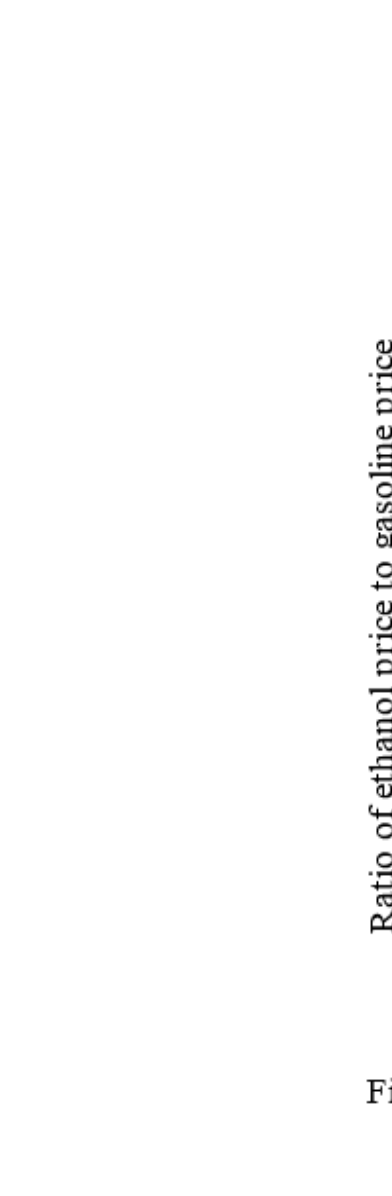$$
\mathrm{Q}_{\mathrm{E}} / \mathrm{QG}_{\mathrm{G}}
$$

(

.

. (1)

\author{
$(2+2$
}

(
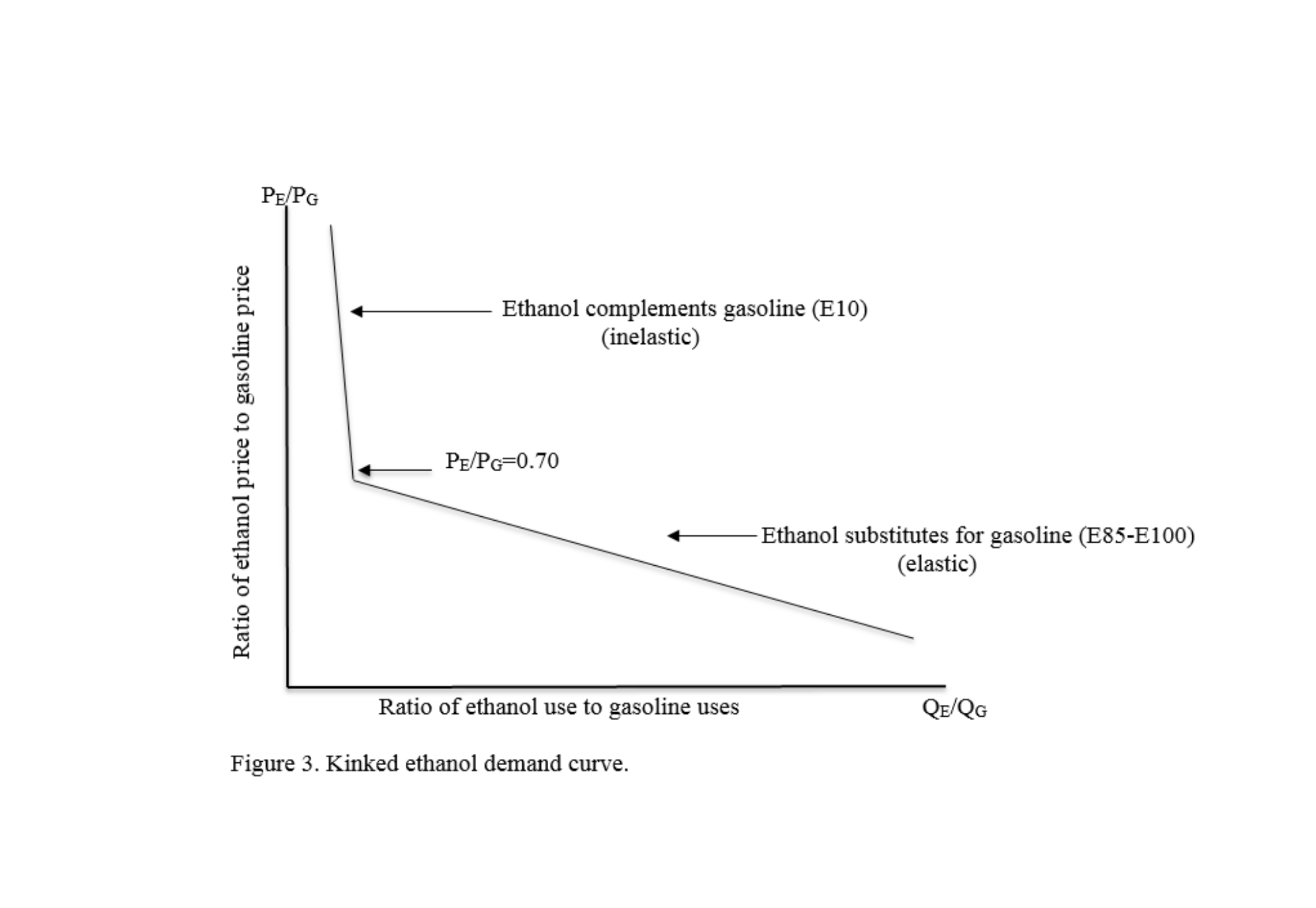


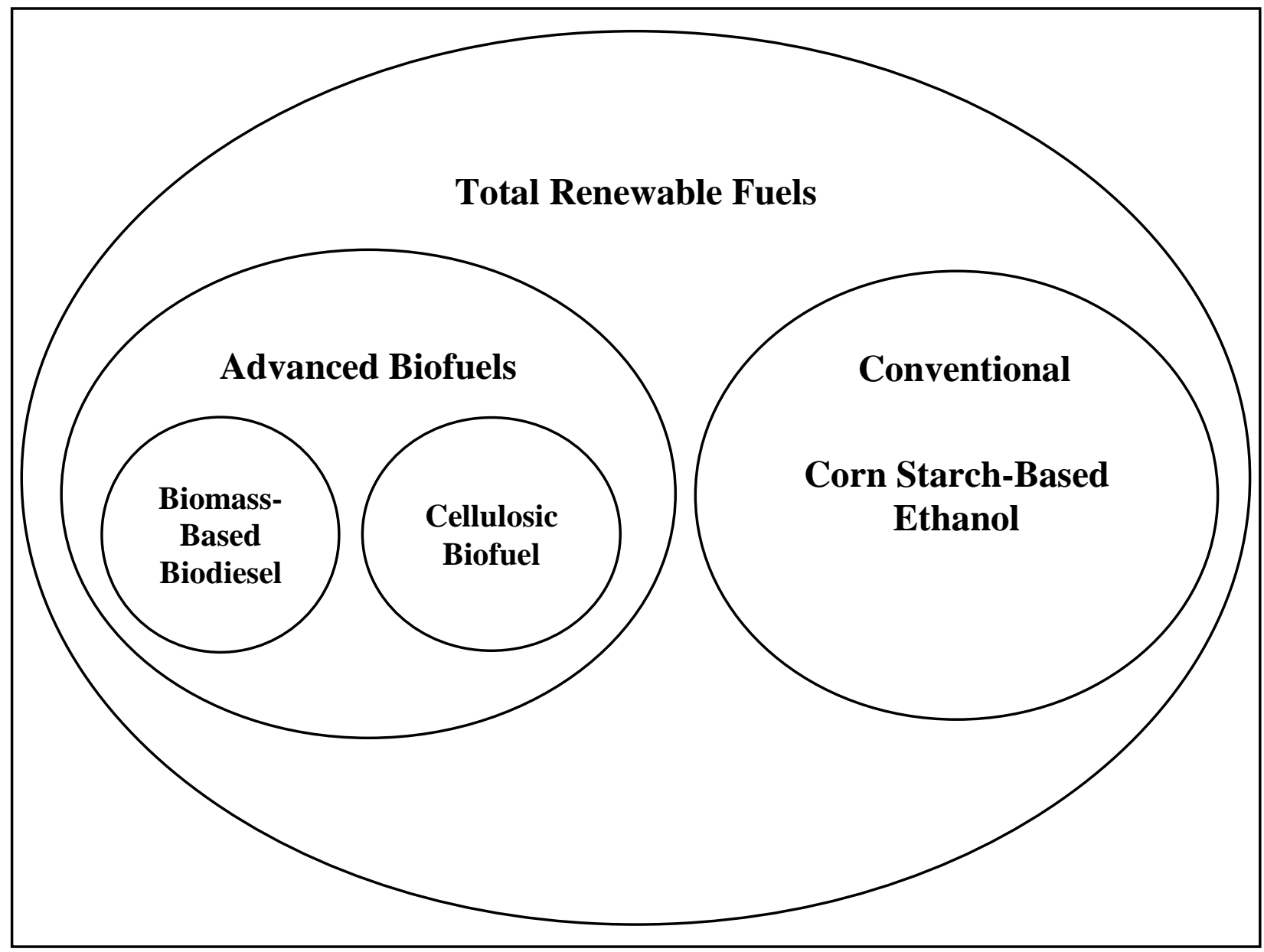

Figure 4. Venn diagram of different categories of biofuels nested under the total renewable fuels according to EISA 2007. 
Figure 5

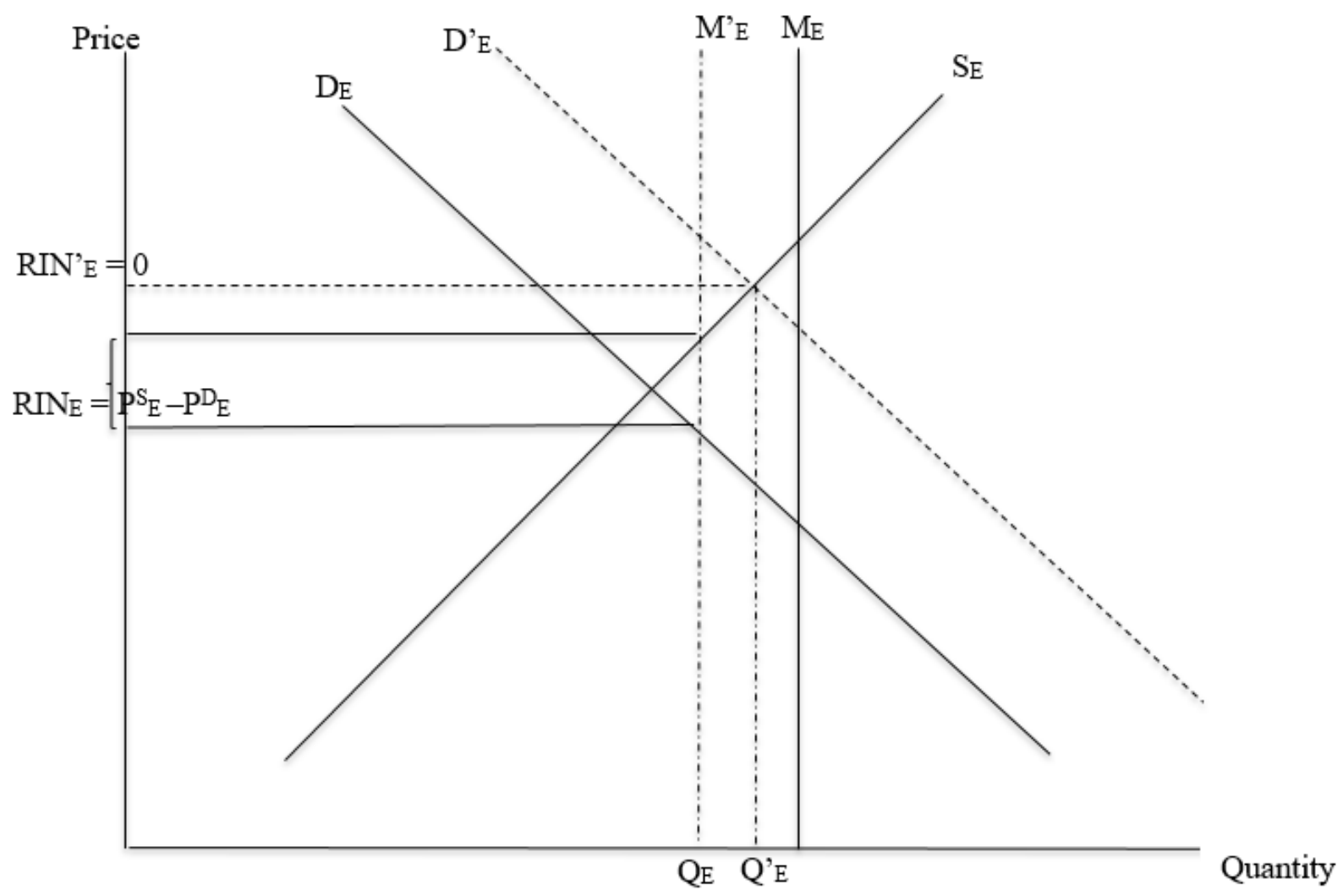

Figure 5. Schematic representation of the U.S. RINs market values under low and high gasoline price. 


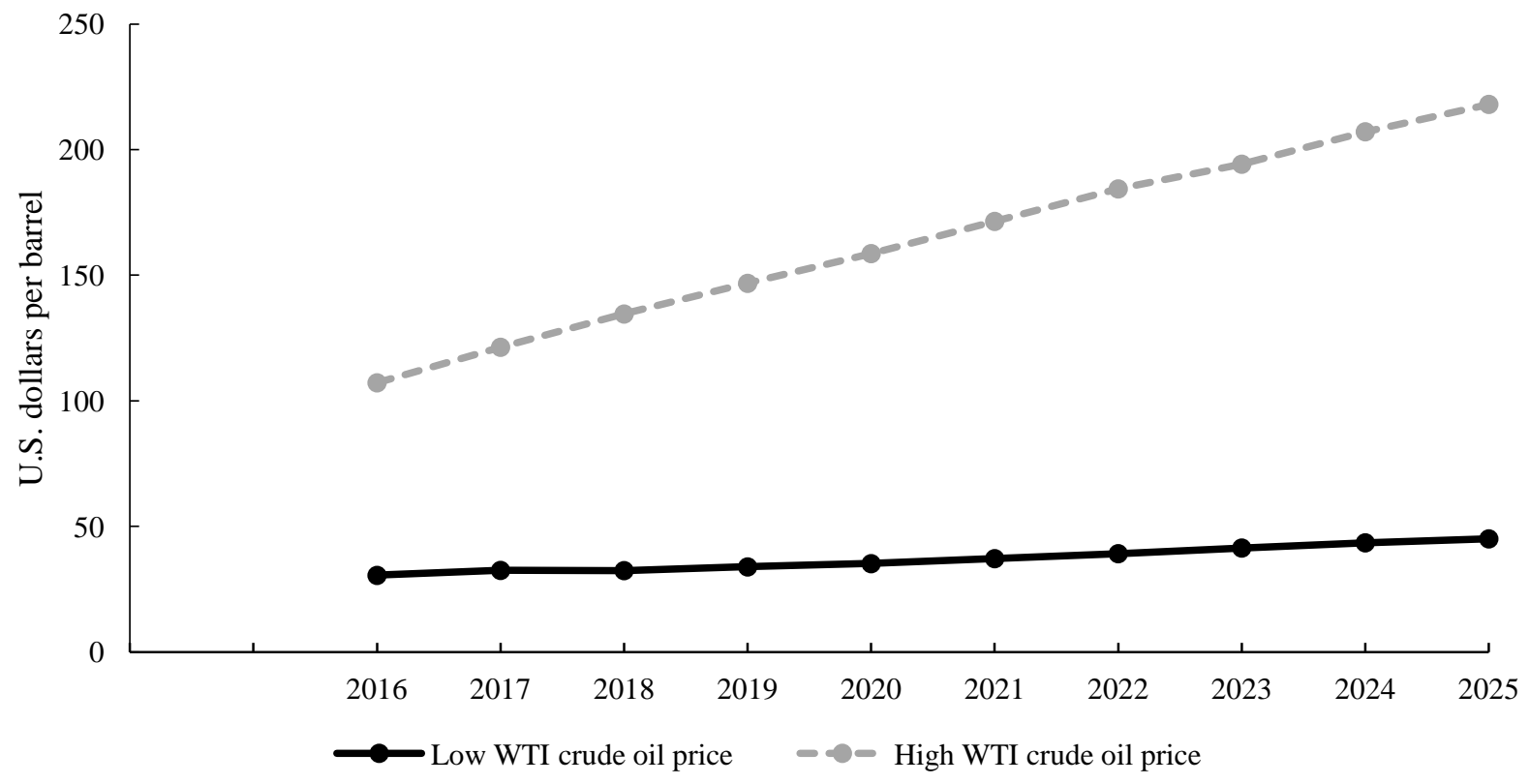

Figure 6. West Texas Intermediate (WTI) crude oil price path assumptions: (i) low crude oil price, and (ii) high crude oil price.

Source: 2016 Annual Energy Outlook [49]. 

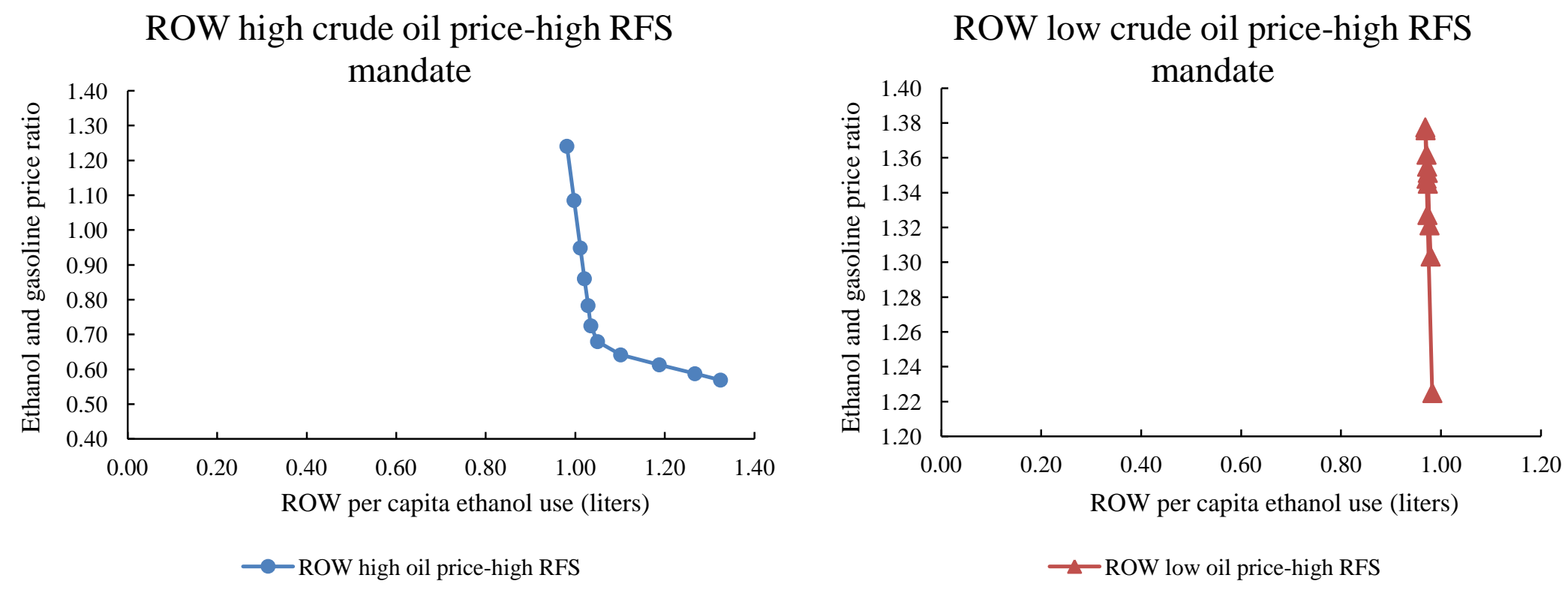

Figure 7. Simulated per capita quantity demand for ethanol in rest of world (ROW).

Note: We use the ratio of crude oil price and Brazilian anhydrous ethanol price as the representative of the world ethanol price. 

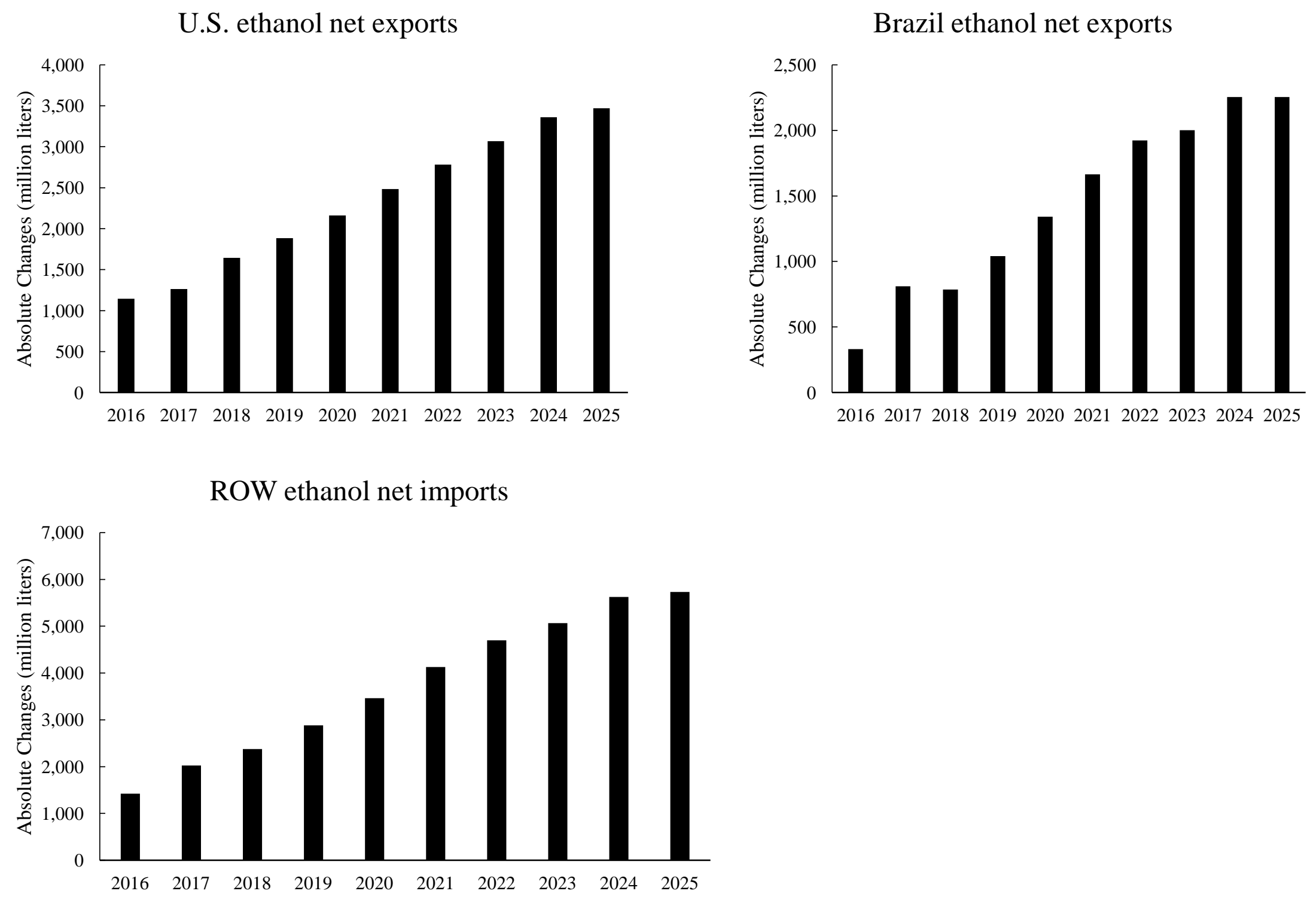

Figure 8. Absolute changes in country specific ethanol trade from low crude oil price scenario to high crude oil price scenario. 